\title{
COLUMBUS RUNS AGROUND: CHRISTMAS EVE, 1492
}

\author{
Stephen Greenblatt
}

At the close of Samuel Eliot Morison's monumental study, The European Discovery of America: The Southern Voyages, 1492-1616, the great historian salutes the ships - Santa Maria, Niña, Golden Hind, and so forth - that carried Europeans across the face of the earth in what he views as a kind of secular Epiphany. This century of voyages was also, Morison observes, an Epiphany in the religious sense: the main conception and aim of Columbus, to carry the Word of God knowledge of His Son to the far corners of the globe became a fact: Christ had been made manifest to a new race of Gentiles. By 1615 the Christian Mass was being celebrated is hundreds of churches from the St. Lawrence through the Antilles to the River Plate, and along the west coast from Valdivia to Lower California. To the people of this New World, pagans expecting short and brutish lives, void of hope for any future, had come the Christian vision of a merciful God and glorious Heaven. And from the decks of ships traversing the two great oceans and exploring the distant verges of the earth, prayers arose like clouds of incense to the Holy Trinity and to Mary, Queen of the Sea ${ }^{1}$. Morison's words, published in 1974 nea $r$ the end of his long and distinguished career, can conveniently stand as the articulation of a traditional position - let us call it "the vision of the victors" - against which virtually all recent scholarship about the initial encounter between Europe and America has been written ${ }^{2}$. It is not that contemporary scholars, diverse in their interests and conclusions, are explicitly concerned to refute this position; it is rather that they seem to inhabit a different century, one that has seen all of the assumptions behind Morison's eloquent sentences decisivelly challenged.

1 MORISON, Samuel Eliot. The European Discovery of America: The Southern Voyages, 1492. 1616 (New York: Oxford University Press, 1974), p. 737.

2 Among the many articulations of this Iraclitional position, one might cite Leonardo Olschki's characterization of Spmnish imperialism as "a activity which transformed within a short lapse of time a rudimentary stone-age scciety into a lively colonial organization" ("What Columbus Saw on Landing in the West Indies", in Procceedings of the American Philosophical Society 84 (1941), p. 635). 
Few people writing about the European voyages of the sixteenth century any longer regard them as marking an Epiphany. This is $\mathrm{nn} /$ because scholars now simply dismiss the Europeans's religious motives. Such a dismissal was characteristic of an earlier critique of colonialist apologetics, a critique exemplified by a famous passage in Gulliver's Travels:

A Crew of Pyrates are driven by a Storm they know not whither, at length a Boy discovers Land from the Top-mast, they go on Shore to Rob and Plunder; they see an harmless People, are entertained with Kindness, they give the country a new Name, they take formal Posoession of it for their King, they set up a rotten Plank or a Stone for a Memorial, they murder two or three Dozen of the Natives, bringing away a Couple more by Force for a Sample, return home, and get their Pardon. Here commences a new Dominion acquired with a Title by Divine Right. Ships are sent with the first Opportunity, the Natives driven out or destroyed, their Princess tortured to discover their Gold; a free Licence given to all Acts of Inhumanity and Lust, the Earth reeking with the Boold of its Inhabitants: and this execrable Crew of Butchers employed in so pious an Expedition, is a modern Colony sent to convert and civilize an idolatrous and barbarous People ${ }^{3}$.

There is, in my view, much to be said for Swift's vision, but it is no more that of most contemporary scholars than Morison's. If in the books published to commemorate the quincentennary of Columbus' landfill in the Caribbean there are few pious sailors hymning the Virgin from the decks of their stout ships, there are equally few cheerily cynical pirates. Even Sir Walter Ralegh, who was rumored in his own time to be an atheist, figures in a spate of new essays not as a man who stands coolly outside the evangelical currents of his time but as someone who was engaged in a complex and often desperate negotiation with values he could neither securely manipulaee nor comfortably embrace. Tother European voyagehs Bartolomé de Las Casas, Diego de Landa, Jeancre Léry, Columbus himself - whose texts have seized the imagination of recent scholars are clearly undersstood to be deeply engaged with the fate of Christianity in the New World (Columbus wanted to be called "Christo-ferens," the Christ-Bearer), but their religious vision and its practical consequences bear little resemblance to that celebrated by Morison.

One feature of the new scholarship that distinguishe it from both Morison and Swift is that in centrably concerned witt what Nathad Wachtel 
valled "the vision of the vanquished." 4 There is a growing sense of alternative histories, competing accounts, and muffled voices. Much current writing attempts in a variety of ways to register the powerful presence of otherness not an abstract, quasi-allegorical figure of the Other, whether brute or victim, but a diverse range of cultures and representations and individuals with whom the Europeans were forced to interact. We have come to realize that between Morison's celebrants and Swift's predators the very possibility, let alone the necessity, of such interaction had been lost. The American natives had in either case been rendered virtually transparent - either as Hobbsean pagans in a state of nature, condemned before the coming of Christianity to lives that were solitary, nasty, brutish, and short, or as mute, naive, miserable victims, condemned only to deception, enslavement, and the irrevocable loss of their pastoral innocence. In contemporary scholarship, by contrast, the encounter between Europeans and Americans is given a remarkable specificity and historical contingency. The indians are beginning to lose the transparency of allegory (the transparency that made them "Indians" in the first place) and gaining instead the density of historical subjects struggling to come to terms with figures from a perplexingly different culture. For their part, the Europeans are no longer understood as symbolic representatives of monolithic traditions, but as figures who are improvising sinous paths throuch fiercely competing claims.

This mutual density does not necessarily signify successful communication. On the contrary, as Inga Clendinnen has shown in a brooding ans powerful essay, "'Fierce and Unnatural Cruelty': Cortés and the Conquest of Mexico," the cultural understandings specific to Aztec as well as Spanish warfare made cross-cultural communication virtually impossible ${ }^{5}$. Neither side could read the other's conventional signals, and is a tangle mutually incomprehensible gestures, even "surrender" became all but impossible. "Where the indicators that mark defeat and so allow 'moral collapse' to occur are not acknowledged," Clendinnen writes, "neither victory nor defeat is possible, and we approach a sinister zone in which there can be no resolution dian Eyes, 1530-1570, trans. Ben and Sian Reynolds (New York: Barnes and Noble, 1977,; orig. pub. in French, 1971) Conquest of Mexico", appears in Anthony Grafton, ed., Culture and Communication in Early Modern Europe (Philadelphia, 1990). My references will be to the Representation version. Clendinnen has related reflections, involving the Maya and the Spanish, in Ambivalent Conquests. 
save death." 6 The crucial point for our purposes is that even failed communication is, as it were, two-way. The Spaniards and the Aztecs shared a common problem, the opacity of the other, and a common desire, the desire to make a meaningful out of the disorienting, almost incomprehensibly violent event in which they were plunged.

The radical incommensurability of these compelling stories plays a crucial role, Clendinnen argues, in the outcome of their struggle - and it plays a crucial role as well in the story that she has to tell. For, as she acknowledges, the historian is by no means ceempt from the compulsion to fashion a coherent and satisfying narative out of the tangled traces of the past. This acknowledgment neads her to skepticism aboutt her own sources, particularly the fragmentary early accounts of the initial clash between the small band of conquistadores and the Aztec empire. She proposes that we resist the Spanish presumption that their civilization gave them a greater access $o$ the mind of the other, and hen e a strategically crucial advantage, a claim that has dominated accounts from the time of Cortés to Prescott in the nineteenth century and to Todorov in our own. For Clendinnen, Cortés is not a model of intercultural understanding, strategic or otherwise, nor is he the embodiment of national calculation. His gift, in her view, lay in his ability "to coax, bully, and bribe his men, dream-led, dream-fed, into making his own gamber's throw; to participate in his own desperatd personal destiny." Her essay is a somber warning against confusing this fantastic exercise a the will - a violent imposition, in effect, of narrative on reality - with the actual knowledge off nother culture.

But if the historihn, herself is pommitted to imposing narrative on reality, how can she avois replicating they very process she is áttemptiog to analyze? There is no simple solutionrto this problem, I think, but one can glimpse in Clendinnen's essay repeated attempts to unsettle the very condition of a coerent and satisfying narrative of these events. Hence her account turns upon a central, structural incoherence, an untranslatability (as much for the Spaniards as for the Aztecs) that had abd, she suggests, continues to have terrible consequences. What looks like communication is non-communication; what looks like relationship is the absence of relationship; what looks like strategic understanding and cultural manipulation is the bloody clash of incompatible and mutually uncomprehending worlds. And the deepest incompatibility is the incompatibility of story-making: Spanish stories trace "an intricate sequence of action" in order to produce "the familiar, powerful 
cumulative explanation through the narrative form"; Aztec stories are founded on a different principle, one based on a conception of time "as multi-dimensional and eternally recurrent." The absolute non-coincidence of these modes did not cause the violent encounter of the Spanish invaders "men without a city," as Clendinnen characterizes them - and the inhabitants of Mexico: blood would have been shed had both peoples understood each other perfectly. But it made it impossible to contain the killing within either culture's established way of managing violence, impossible to contain the killing within either culture's established way of managinh violence, impossible to bring the war to a close until the men without a city had utterly destroyed the city they had meant to conquer.

We can perhaps usefully apply to the situation Clendinnen describes a concept that Fernand Braudel terms "the structure of the conjuncture." This term, as adapted to Marshall Sahlins, would here refer to the intersection of four complex elements: the operative cultural understanding of the Europeans, the historical situation in which this understanding is deployed, the operative cultural understanding of the natives, and the historical situation in which this understanding is deployed. There is no symmetry among these elements, not only because the cultural understandings are obviously so. different, but because the historical situations, though superficially identical (ships arrive, objects are traded, blows are struck), are in fact equally different. For an historical situation is never simply that of the moment: it is the expression of long-term trajectories, material necessities, social structures, enduring, largely unconscious patterns of will and constraint, not necessarily identical with the culture's own understanding of itself.

So there four pieces converge, and the convergence has its own structuring force, quite apart from what any of the participants may be thinking. And the crucial point, for our purposes, is that the asummetry, the inevitable misfist, intensifies the need to construct as explanatory text, an authoritative narrative.

Faced with the challenge of radical difference, both Europeans and natives often behaved as if groping their way blindly through dense fog. The problem posed for action and understanding alike, in the wake of the European arrival in the Americas, is the need, as Anthony Pagden puts it, "to create a text where none had existed before" and "to make the next, once created, authoritative."

7 PAGDEN, Anthony. "Ius et Factum: Text and Experience in the writings of Bartolome de Las Casas", in Representations 33 (1991), p. 150-151. 
GREENBLATT, Stephen. Columbus runs aground: christmas eve, 1492.

tempts to translate the practices of the alien world he observes into the practices and, above all, the discourse of his own. This attempt to reduce the distance between the self and the other by "direct substitution" - seeing native birds as "nightingales", experiencing the climate as that of "May in Andalucia", characterizing native leaders as "kings" - is one of the enduring principles of the early European response to the New World, but it is also set against the opposite response, an intermittent recognition of the baffling and confounding othermust grant the discours of the colonizers a comparable impurity. Their texts are overdetermined, crass-crossed by tiny fracture lines, characterized by unresolvable contradictions. These contradictions have famously plagued interpretation of the first European account of the New World, Columbus's so-called letter to Luis de Santágel, for which we now have as alternate version, thanks to an astonishing recent discovery by Antonio Rumeu de Armas of an authenticated sixteenth-century copy of Columbus's Libro Copiador, his "copy book". The alternate version differs significantly from the celebrated letter that circulated in Europe in the wake of Columbus' first voyage, and its startling resurfacing after so many centuries subjects that letier still further to what Louis Montrose calls "epistemological and ideological destabilization."

The Libro Copiador version makes more visible the peculiar yoking in Columbus' rhetoric, and perhaps in his consiousness, of piety and greed, the longing to recover for Christiabity the holy places of Jerusalem and the equally intense longing to get the natives' gold in exchange for trash. It brings Columbu's public rhetoric closer then to the radical instability of the $\log$ book or diary. The emblem of that instability (and one of its contributing causes) is the fact that the text we have is an abstract by Bartolomé de Las Casas of copy of the lost original. Las Casas may have been reasonably faithful to the Admiral's words (to the extent that they were themselves accurately copied) - the degree of this fidelity has been vigorously challenged recently in a book by David Henige - but his own interests, intellectual and rhetorical, are unmistakably apparent not only in his marginal glosses but in the body of the text. Where we might have looked for one man's words, however complex, we find as least two and possibly more.

In the time that remains I want to examine a particularly revealing passage in Columbus' Diario, a passage in which the need to construct a coherent "text", the destabilization of that text, and the problem of inter-cultural communication are all highlighted. But I want first to sum up the principles that seem to me to characterize the new directions in New World scholar-ship.

First, as assumption of textual opacity. We must start from the conviction that discourse neither can nor should be rendered transparent. Our 
principal access to the European encounter with the New World is through what Michel de Certeau (whose difficult but incomparably intelligent work set the agenda for much current scholarship) calls the colonists' "scriptura economy". Writing is itself freighted with meaning, paricularly in relation to peoples whose identity is repeatedly characterized as bound up with their supposed lack of even the most rudimentary writing. The scholar's goal must not be to strip away or look behind European texts in order to discover the naked truth. The problem is not there is no truth or that we are forever doomed to ignorance - though considerable ignorance is certainly inescapable in these matters - but that the discourses of colonialism are actually doing much of the crucially important work of colonialism. Consequently, if we treat the texts as clear or even as distorting windows, we inevitably miss much of what we most need to understand.

Second, a recognition of textual complexity. The early European accounts of the encounter are not monolithic or single-minded. We must concern ourselves with the haf-hidden stress points in the official voices, the tensions, ideological negotiations, and rifts that are often plastered over in later accounts and all disappear from view. Many of the texts we study are complex intertwinings of potencually competing discourses, systems that are periously close to explosion or colapse. It was, de Certeau argued, Montaigne's genius in "Of Cannibals" to bring matters to a crisis: the rival discourses "destroy one another as soon as they touch: a shattering of mirrors, the defection of images, one after the other." 8 By contrast, in much of what we read from the late fifteenth and sixteenth centuries the rival discourses are locked in an uneasy embrace.

Third, a search for textual otherness. The voices of the other do not reach us in pure o uncontaminated form - as if such a condition were ever possible! Indeed the whole European project of writing about the New World rests upon the absence of the object - lanscape, people, voice, culture - that has fascinated, repelled, or ravished the writer. "The scriptural operation which produces, preserves, and cultivates imperishable 'truths'", de Certeau writes, "is connected to a rumor of words that vanish no sooner than they are uttered, and which are therefore lost forever. ${ }^{\prime 9}$. Yet despite this loss, the University Press, 1988), p. 212. 
"rumos of words" must somehow be attende to. The difficulty of this task is the subject or much current work, as is the peril of a failure to attend.

Fourth, and finally, a questioning of textual authority. Once they are written, texts do not simply appear in the world (or routinely survive in archives): they are marked,placed, licensed, authorized. "Writing", de Certeau observes, "designates an operation organized about a center." ${ }^{10}$ But in the case of the New World, the center very often does not hold. Textual authority is fraught with particular difficulties, not only because of perennial tensions in overburdened command structures, but because of the immense distance from Europe of the newly discovered lands and, consequently, the immense problem of verification, a problem exacerbated by the strangeness of the stories that had to be told. At the moment that Europeans embarked on one of the greatest enterprises of appetite, acquisition, and control in the history of the world, their own discourses became haunted by all that they could not control. They had embarked, without quite realizing it, upon "a subtle, permanent, practice of distances" 11 .

Let us turn now, on our way to Columbus's Diary, to a very distant text. In the sixth century Life of St. Brendan, a father decribes to the Irish saint a mysterious island that had been visited by his son, the monk Meruoke, in the company of other monks who had sailed there. The earth of the island shone as bright as the sun; there were flowers everywhere, and "the fairest trees and herbs that ever any man saw", and many precious stones, "so that it was a glorious sight and a heavenly joy to abide there". A fair young man came to the monks and courteously welcomed them, calling each by his name and telling them that the place was called "Paradise Terrestre". The visitors thought that they had only been on the island for half an hour or less, but the young man informed them, to their astonishment, that they had been there already for half a year, with neither meat, drink, nor sleep, so great was their mirth and delight. For this, he explained, is the place where Adam and Eve first dwelt and would have remained, had they not broken God's commandment. And then the young man brought them to their ship again and said that they might no longer abide there. Fired by this wonderful account, St. Brendan set out to find the island and, after a series of magical adventures that manifested God's grace and mercy, he eventually succeeded. This poigment little story is so close in some of its details to Columbu's initial expperience in the New World that it is tempting to think that he had ie in his

10 The Writing of History, p. 217.

11 CERTEAU, Michel de. in Heterologies, p. 68. 
mind when he wrote the entries in his Diary. He would certainly have heard of St. Brendan and would have thought about his elusive island, at once shrouded in myth and confidently depicted west of the Canaries on fifteenthcentury maps. Persistent sightings of the island and endlessly iecycled accounts ofrits eaquisite beauties may have shaped Columbu's perceptions and, in any case, probably licensed his narrative of those perceptions, his selffashioning, his adoption of what we mayorall the St. Brendan strategy. For Columbus and his financial backers could, after all, have been disappointed by what he found - islands with innumerable small villages but no major cities, no signs of advanced material culture, no silks and spice markets and gorgeous palaces - and could have concluded that the marvelous tales of Cipango were a myth or that the kingdoms Marco Polo had visited in the fourteenth century had sadly decayed. Thus, for example, Sir Antony Shirley tiavelled in the early seventeenth centuiy to the legendary island of Cyprus and discovered that there was no "there" there: "wee found nothing to answere the famous relations giuen by ancient Histories of the excellency of that Iland, but the name onely, (the barbarousnesse of the Turke, and time, hauing defaced all the Monuments of Antiquity) no shew of splendor, no habitation of men in a fashion, nor possessors of the ground in a Principallity"12.

Columbus' island lacked precisely what Shirley was looking for monumental splendor, fashionable habitation, imposing signs of a principality - but he describes them in the language of intense wonder and delight: "The island is the most beautiful thing that I have seen... I do not know where to go first; nor do my eyes grow tired of seeing such beautiful verdure and so different from ours" (October 19, 1492). He had not encountered the golden pavilions and cloud-capped towers of the Grand Khan, but he had reached an achingly beautiful land inhabited by people of infinite kindness and docility. Of course, it was in Columbus' interest to praise what he had discovered, but we need to grasp the special rhetorical power of the St. Brendan strategy, its ability to turn apparent defeat into triumph. Columbus declares himself, like the Irish monks of old, overwhelmed with the limitless fertility of the land, the extraordinary beauty of its trees, the courtesy of its gracious and gentle inhabitants. If he did not stumble on precious stones, there was a least the promise of vast quantities of gold, gold that adhered to the barrel hoops when the sailors filled the casks with river water, some of the grains as large as lentils. (Morrison, p. 309). And if he did not 
think that he had reached the Earthly Paradise, his account could suggest that he was very, very close. The admiral could not claim to do without food or drink, of course, but fresh water was abundant, and the natives' apparently boundless generosity meant that he had to give very little thought to provisioning the ships.

The one thing that Columbus absolutely could not dispense with, however much he might have wished to, was sleep. He had not, after all, actually reached paradise, and the miraculous dispensation granted to the Irish monks was not his. To be sure, Columbus knew sleeplessness, but only as a vexation that increasingly tormented him as the years passed. Perhaps he exaggerated his insomnia, to emphasize his tirelessu ervice to his sovereigns. But it is also possible that the escitement and anxiety of the voyages, the desire to see and also the fear of the unseen, kept him awake. He was, after all, consumed with the desire to witness everything for himself and not only for himself: in a world without photography and, more to the point, on a voyage evidently without an artist, Columbus was the principal pair of eyes. (Later voyages would occasionally include trained artists - in England the most famous sas John Whipe - but apparently it occured to no one to do so in 1492).

There is a strange moment in an early sixteenth century proposal to Henry VIII in which the author, Richard Thorpe (check name), declares that it is actually to England's advantage that the Spanish have monopolized allmof the southern latitudes and have consequently forced all subsequent explorers to the farhnorth. For in the north, the sun does not set, so that there is never any night, and therefore explorers will never be forced by the darks to miss important discoveries. Thorpe's is a classic instance of a grant proposal weak on the dntails, but the anxiety that drives the concept is clear enolgh. And it is an anxiety that appears at times to have kept Columbus awake. We happen, in any case, to know of a night when he decided finally to get some rest. The night was Christmas eve, 1492, the sea was "as smooth as water in a bowl", and the Santa Maria was sailing in light wnd off the north coast of Hispaniola. In Las Casa's transcription of the Diario, at 11:00 p.m. "the Admiral decided to go to sleep because there had been two days and a night when he had not slept"13.

Diario, p. 277. Morison imagines, moment of pious reflection: "He thanks God for another day's safe sailing, and for sending His only begotten Son to redeem the world. For a few moments he ponders on that scene in the stable at Bethlehem, then says an Ave Maria and falls into a deep sleep, his first in over forty-eight hours" (in Admiral of the Ocean Sea: A Life of Christopher Columbus (Boston: Little, Brown and Company, 1942), p. 298. 
Unfortunately, the officer in charge also decided to go to sleep, leaving the tiller in the hands of a ship's boy who did not notice that the current was carrying the ship toward a coral reef. The Santa Marianslid onto the reeft and the frantic efforts of Columbus - who was now awake again with a vengeance - and his men could not succeed in freeing it. As the planking began to open up, there was nothing to do but to try to save the crew and to salvage the ship's cargo. This was done but not by the Spanish alone, for the Pinta, under Martín Alonso Pinzea, had characteristically sailed away on her own and the Niña, though nearby, could not come too close for fear of running aground herself. Instead the rescue was accomplithed by the Indians in canoes sent by their "king" Guacanagarí with whom Columbus had for several days been in contact and who "cried", as it is reported, when he heard of the unfortunate accident.

What is the meaning of Guacanagari's tears? They are noted repeatedly, as when, according to the Diario (Decemberah 6), he came in person to Columbus, by then relocated on the Niña, and "almost weeping (quasi llorando) said to him not to be downhearted for he would give him all that he had", and yet again when "he sent one of his relatives to the Admiral, weeping, to console him, saying that he should not be sorrowful or annoyed because he would give him all that he had". Morison thinks that in this last passage it is the Admiral who is weeping, but the phrase is ambiguous, and the other examples would seem to tilt all the crying toward the compassionate Indians.

For Columbus the tears, along with the diligent practical assistance in salvaging virtually everything "so that not a laceend would be missing", are signs of the goodness of the Taino king and his people. "He and the whole town were weeping", the Diario reports (December 25); "to such a degree, the Admiral says, are they loving people and without greed, and docile in everything. And I assure your Highnesses that I believe that in the world there are no better people land. They love their neighbors as themselves, and they have the sweetest speech in the world; and (they are) gentle and are always laughing. They go about as naked, men and women, as their mothers bore them, but may Your Highnesses believe that among themselves they have very good customs, and the king (observes a) very wonderful estate (muy maravilloso estado) in such a dignified manner than it is a pleasure to see everything. And the memory that they have! They want to see everything and ask what it is and what it is for! All of this the Admiral says" (281).

Las Casas is careful to note that this is not merely his own homage to the gentle Taino, but the Admiral's very words, a kind of official certification of their goodness (for the verb translated as "assure" is in fact certificar). The point is important to Las Casas because his whole polemical project involves 
setting the goodness of the natives - who instinctively follow the gospel teachings - against the unspeakable wickedness of the Spaniards: "note here", he writes in the margin alongside the account of the Taino's kindness, "the Humanity of the Indians toward the tyrants who exterminated them". For Las Casas the story is one of betrayal, "humanidad" answered by enslavement and murder. The shipwreck of the Santa Maria is a foundational moment fos Las Casas, for it reveals in unequivocal terms the moral nature of the Indians, their charity and lovingkindness in response to the momentarily vulnerable invaders, just as the moral depravity of the Spanish is starkly disclosed by their cruel exploitation of the vulnerability and meekness of the Indians.

Columbu's view of the larger significance of Taino generosity, of course, is different from Las Casas'. The shipwreck came about because the human necessity of sleep forced him to relax his will, and with this relaxation of the will came disaster. But the effects of the disaster are greatly minimized through the Indians' extraordinary care: "The Admiral assures the sovereigns (again the verb is certificar) that in no part of Castile could they have taken such good care everything" (281). As we have already glimpsed, Columbus' image for this remarkable attentiveness is that not so much as a lace-end (un. aqujeta) is missing, an image that recurs in his concluding remarks about the shipwreck: "The Admiral concludes saying that of everything that was in the ship not even a lace-end was lost" (291). The point is not only that nothing was lost to the sea - one thinks of the "dangerous rocks", in The Merchant of Venice, "Which touching but my gentle vessel's side/Would scatter all her spices on the stream,/Enrobe the roaring waters with my silks,/And in a word, but even now worth this,/ And now worth nothing" - but also that nothing was lost to thievery. The absence of pilfering - not so much as lace-end or, as Columbus puts it elsewhere, a crumb of bread (una migaja de pan)demonstrates, he says, to what a degree "are they faithful and without greed for what is another's, and, above all, so was that virtuous king".

It is exactly at this moment of testimonial that Columbus introduces a crucial detail that begins to transform his story from an account of salvage to an account of salvation. While he was talking to the virtuous king, "another canoe came from another place bringing certain pieces of gold which they wished to give for one bell, because they desired nothing else as much as bells". The Indians then at a stroke reveal that they possess gold and that they are willing to exchange their gold for worthless things, a willingness immediately confirmed by a sailor who reported to the Admiral that "it was a thing to marvel at, the pieces of gold that the Christians who were ashore traded for a trifle. For a lace-end they gave pieces that would be more than two castellanos" (283). The Taino artefacts - pendants and earrings and figurines bound up with the aesthetic and religious values of their culture - 
have been reconceived first as "pieces of gold" and then as Spanish coins. And the aqujeta, symbol at once of the most trivial object and of the Indians' scrupulous honesty, returns as treasure.

The dream of an unequal exchange is immensely alluring, of course, but it is also potentially disquieting, for it would seem to fuel the moral outrage that Las Casas articulates. Columbus is not completely indifferent to the moral problem, if only because the language with wich he has described the Indians in using what I have called the St. Brendan strategy is so admiring: "They love their neighbors as themselves". There are constraints as well as entitlements buit into Columbus' rhetorical strategy: he must somehow accomodate the implications of the terms he has deployed. These terms appeal to ethical values that cannot be crudely tampled; they have rather to be trampled with some delicacy. The sense of a swindle is reduced slightly by the argument that the Indians simply do not value gold, an argument that is at least as old as Mandeville's Travels where we read that in China and India "clothes of gold and of silk be greater cheap there a great deal than be clothes of wool", while "the gold and the precious stones and the great orient pearls be of greater value on this half the sea than they be beyond the sea in those countries"14. So Columbus, who a few days before had noted that he could not understand a word that the kings was speaking, now writes in his log book that "the king gave him a report and, in particular, (said) that there was gold in Cipango, which they call Cybao, in such degree that hold it in no regard" (285).

All the same, Columbus evidently feels that the docile, compassionate Indians must in fairness get something more for thoir argument that the Indians simply do not value gold, an argument that is al least as old as Mandeville's Travels where we read that in China and India "clothes of gold and of silk be greater cheap there a great deal than be clothes of wool", while "the gold and the precious stones and the great orient pearls be of greater value on this half the sea than they be beyond the sea in those countries"15.

Mandeville's Travels, ed. Malcom Letts, 2 vols., Hakluyt Society 2nd Series 101-2 (London: Hakluyt Society, 153 1:161-2. I have used the Cotton MS readings.

15 This claim is puzzling, especially in the light of hie earlier remark that the Taino king had ordered that all of the salvaged goods be stored in several houses and that "he placed armed men (hombres armados) Saround everything and ordered that they keep watch all night" (281). It is remotely possible that Las Casas' transcription has junbled Columbus' own orders and that of the native rulertebut it seems more likely that, in his celebration of the natives' docility and his enthusiastic description of their completely vulnerability, Columbus conveniently forgotten his own earlier observation. 
So Columbus, who a few days before had noted that he could not understann a word that the king was speaking, now writes in his log book that "the king gave him a report and, in particular, (said) that there was gold in Cipango, which they call Cybao, in such degree that they hold it in no regard" (285).

All the same, Columbus evidently feels that the docile, compassionate Indians must in fairness get something more for their gold than aqujetas. That something is the power to kill. Columbus reports that be natives he encountered had no weapons, but that they spoke about some men whom they called Caribs who came with bows and arrows to capture them. Speaking in sign language, Columbus told the king "that the sovereigns of Castile would order the Caribs destroyed, and they would order all of them to be brought with hands tied" (287). Having explained his plan - or imagining that he had explained in through the charades he must enacted - the Admiral proceeded to fire his cannon at which the king marveled and the people fell to the ground.

It needs only to function rhetorically, as it still does some half century later, for example, in the pro-Spanish writing of the Englishman Richard Eden who translated Peter Martyr's account of Columbus's voyage. The Spanish should be commented for "their merciful wars against these naked people", wars in which the vanquished have gained more than the victors. Some will say, Eden concedes, that the Spanish have robbed and enslaved those who innocently welcomed them, but in fact "they have taken nothing from them but such as they themselves were well willing to depart with... as gold, pearls, precious stones and such other, for the which they recompensed them with such things as they much more esteemed". And as for their bondage, it is "much rather to be desired than their former liberty which was to the cruel Cannibals rather a horrible licentiousness than a liberty, and to the innocent so terrible a bondage, that in the midst of their fearful idleness, they were ever in danger to be a prey to those manhunting wolves" ${ }^{16}$. Charity and theft, protection ans oppression, liberty and bondage have their meanings

16 EDEN, Richard. Dedication of translation of $2^{\text {nd }}$ decade of Peter Martyr (translations cone to commemorate marriage of Mary to Phillip II, published in 1555). The passage continues: "But now thanked be God, by the manhood and policy of the Spaniards, this devilish generation is so consumed, partly by slaughter of such as could by no means be brought to civility, and partly by reserving such as were overcome in wars, and converting them to a better mind, that thewlrophecy may herein be fulfilled that the wolf and the lamb shall feed together... The Spaniards as the ministers of grace and liberty,brought unto thesc new gentiles the victory of Christ's death". (Arber, p. 50). 
conveniently reversed in arguments that can alo be traced back to Columbus's journal entry in the wake of the shipwreck.

In that journal entry these reversals are part of a single, overarching rhetorical project: the transformation of disaster - this is an admiral whose ship has run aground when he was asleep - into triumph. At the sight of the Indians' gold, the Diario records,"the anguish and sorroc that he had .h. . felt because of the loss of the ship gere tempered; and he recognized that Our Lord hadacaused the Ship to ground there so that he woule found a settlement" (287). The discursive strategy here has moved away fram St. Brendan - we are no longer wuite in the suburbs of the 1 rthly Paradise - and toward the ehic romance: the shipwrecked hero will save the innocents from their cruel oppressores and will found a city. What looked like a failure consequent upon a dangerous relaxation of the will is reveaked to be operation of a higher will ${ }^{17}$. In the service of this will - for the Admiral, Las Casas notes, "adds more to show that it was great luck and the particular will of God that the ship ran aground so that he would leae people there" - Columbus determines not to take the crew of the Santa Maria back with him to Spain (something that might, in any case, have been difficult to do) but to leave them on the island in a fortress constructed with the ship's timbers and provisioned with ots supplies. The fortress, he writes, is not really necessary from a military poin of view, for a few armed men could subbue the entire island, but it usefully displays to the Indians "the skills of Your Highnesses' people and what they can do, so that with love and fear they will obey them" (289).

It ios not obedience, however, that Columbus envisages at this point but exchange, the marvelous trading of aqujetas for pieces of gold. The fort is well-stocked with trofles, so that when he returns, he hopes to find "a barrel

Colombo, nei suoi appunti, nelle postille a mlrgine dei te ti da lui utilizzati per progettare il suo viaggio, nel suo Diario de Bordo e piú generalmente nei suoi scritti, palesa la concezione mistica e messianica della sua vitta; egli si sente strumento delli volontà divina per compiere i disegni voluti da Dio nel ciclo della creazione; a questo proposito Colombo elabora delle complesse considerazioni riguardanti la durata del modo, desumendole dalla lettera delle Tavole Alfonsine. Queste concezioni, sparse un po' dovunque in quei testi, ma particularmente nel trattato sul calendario, sono integralmente tratte da un testo cabalistico, che era stato scritto due anni prima della compilazione della Tavole, il Sefer ha Temunah, libro della figura, nel quale si sosteneva appunto Ia teoria della ciclicitì della creazione". Guido Nathan Zazzu, "Genova e gli Ebrei: Caterina Procu Sanna, eds. Christoforo Colomlo nella Genova del suo tempo (Torino, ERI, 1985), 219. The key point here for my purposes is the notion of the instrument of a divine will playing off against the triumph of the will under wgich so muchs of Columbus' life seems to occur. 
of gold that those who were left would have acquired by exchange". With this and with the still greater amounts of gold that he expects that his men will find when they locate the Indians' mines, the Spanish sovereigns, Columbus writes at the end of his momentous diary entry for December 26, "will undertake and prepare to go conquer the Holy Sepulcher; for thus I urged Your Highnesses to spend all the profits of this my enterprise on the conquest of Jerusalem, and Your Highnesses laughed and said that it would please them and that even without this profit they had that desire" (291).

Sleep, shipwreck, salvage, salvation. Though he seeks his own advantage and that of his sovereigns, the salvation Columbus envisages is not simply personal, or even national. The reconquest of Jerusalem is the triumph of Christendom and a crucial part of an apocalyptic design. Progress toward that great end was already apparent in Spain on the eve of Columbus' departure: the fall of Granadaon January 2, 1492, after a campaign of extraordinary cruelty, marked the end of Muslim Spain, while a decade of inquisitorial torture and burning of so-called Judaizers culminated in the same year in the expulsion of the Jews. The final deadline for their departure from Spain was August 2, 1492, the day before Columbusset sail.

"Your Highnesses laughed". Perhaps the laughter of the great is always somewhat chilling. What did it signify? Thriled recognition of their own apocalyptic dreams? Pleasure at the prospect of the recovery of the Holy Sepulcher, in the wake of the glorious triumphs over the Moors and the Jews? Amusement at the distance between Columbus' modest means and his great expectations? Playful dismissal of the presumptuousness of a servant who attempts to dictate the uses of imaginary profits that are not his to dispose? ${ }^{18}$ Let us acknowledge that if their laughter was enigmatic, so too were the tears of the Taino. Columbus thought he knew the meaning of those tears- "to such a degree", he writes, "are they loving people (gente de amor)" (281). But tears, like smiles, can mean many things. They can signify compassion or docility or weakness. They can be the sign of a spontaneous overflow of feeling or, alternatively, of a prescribed ritual. They can mark fear or distress, such as a people may feel at the sudden arrival of unwanted guests. Or they can have meanings that from the outside and at a distance we can scarcely reconstruct. 
By the mid-sixteenth century, the Taino were all dead of disease, violence, overwork, starvation, or despair. We know very little about them. Columbus evidently made few inquiries about their beliefs, and he seems not to have noticed - or perhaps he chose not to register - the fact that they possessed a rather complex material civilization. One of the few large-scale objects from their culture to survive the devastation is a wooden statue of a male figure, found in a cave in Jamaica where it many have been hidden. The statue is thought to represent one of the Taino deities, or zemis, possibly Boinayel the rain giver. He is standing naked, legs wide apart, arms on his hips, and he is weeping, the tears like molten lead carving deep groovers in his cheeks.

Columbus's diary has a magical way of transforming catastrophe into victory, but rhetorical magic has its limits. The next year, when he returned to the settlement he had called La Navidad, Columbus did not find his barrel of gold. He found that all of men he had left there had been killed. 